\title{
Alternative Responses of Policy to External Supply Shocks
}

DURING 1973 and 1974 reductions in supplies of food (through natural causes) and of oil (through unnatural causes) simultaneously lowered the real income of U.S. nonfarm workers and raised the rate of inflation. An inflation-cum-recession induced by lower supplies of raw materials may call for a policy response different from the traditional tonic of demand restriction called for by a "garden-variety" inflation generated by excess demand.

In light of the novelty of the 1974 situation, the sharp divergence of policy recommendations among economists is not surprising. Some analyzed the episode within the context of standard macroeconomic demand analysis, treating the 1973-74 acceleration of inflation as a delayed consequence of the acceleration in monetary growth during 1972 , and the 1974-75 recession as a delayed consequence of the sharp deceleration in monetary growth that began in June 1974. The policy advice of this group, consisting largely of economists generally identified as "monetarists," was to maintain a constant or even slightly reduced rate of growth of the money supply. ${ }^{1}$ Arthur

Note: This paper was supported by National Science Foundation Grant GS-39701. It was inspired, as was a previous paper in another area, as an attempt to reconcile the views of Milton Friedman and Arthur Okun. I am grateful to Michael Parkin and participants in the Brookings panel for helpful suggestions.

1. See Allan Meltzer, "A Plan for Subduing Inflation" (a dialogue between Allan H. Meltzer and two editorial staff members of Fortune), Fortune, vol. 90 (September 1974), pp. 112ff. In the same month, when the money supply $\left(M_{1}\right)$ had risen 5.8 percent over the preceding twelve months, Milton Friedman wrote: “. . . until a few months ago at 
Okun put forth the contrasting view that an attempt by policymakers to maintain fixed growth in nominal income ignored the "macroeconomic externalities" of commodity shortages: total real output falls by more than the decline in farm output, through an extra induced loss of nonfarm output. $^{2}$ An implication of Okun's argument is that, while stabilization policy cannot re-create the lost farm output, it can minimize or eliminate the induced loss of nonfarm output by promoting a higher growth rate of nominal income.

The inflation in 1973 and 1974 can be regarded as a combination of an underlying "hard-core" inflation, inherited from the 1960s and perhaps aggravated by the rapid pace of economic expansion between 1971 and 1973, with a set of four temporary "bubbles": (1) the 1972-74 shortfall of farm supplies to U.S. consumers, caused in the first two years by buoyant foreign demand and in the third by domestic supply shortages; (2) the restriction of oil production enforced by the cartel of the Organization of Petroleum Exporting Countries (OPEC); (3) the end of price and wage controls in 1974; and (4) the devaluations of the dollar in 1971 and 1973. Although these events may have permanently raised the price level, such a one-shot rise generates only a temporary increase in the rate of inflation. ${ }^{3}$

This paper deals with the issues raised by an inflation initiated not by excess demand but by commodity shortages. Although its formal analysis treats an external shock that takes the form of a decline in farm output, its basic conclusions apply with only minor changes to the cases of oil and devaluation. What policies are available to minimize the indirect effects on output? What are the conditions under which expansive policy actions

best, these high interest rates have been accompanied by extremely high rates of monetary growth. ... Recent rates of monetary growth are not too low. If anything they are still too high to bring inflation to an end in a reasonable period of time." See Milton Friedman, "Is Money Too Tight?" Newsweek, vol. 84 (September 23, 1974), p. 82. Friedman's stand on monetary policy was taken despite his recognition that special factors had contributed to the 1974 inflation. He attributed roughly half of it to increases in oil and food prices, to the lifting of price controls, and to precautionary increases against renewed price controls. See Milton Friedman, "Inflation Prospects," Newsweek, vol. 84 (November 4, 1974), p. 84.

2. Arthur Okun, "Incomes Inflation and the Policy Alternatives," in "The Economists Conference on Inflation, September 5, 1974, Washington, D.C.; September 23, 1974, New York, New York," vol. 1, "Report” (1974; processed), pp. 365-75. A formal analysis of the externality argument is presented below.

3. The list could perhaps be expanded by two smaller bubbles-the increases in prices in fear of reimposition of controls, and the overshooting of commodity prices beyond the levels justified by shortages due to speculative inventory hoarding. 
taken to counteract a temporary decline in farm output will cause a permanent increase in the rate of inflation? What are the relative advantages and disadvantages of income-tax reductions, food subsidies, and expansive monetary policy as policy responses? Finally, how would universal escalation (or "indexation") of wage contracts affect the results of the analysis?

\section{The Polar Cases}

To establish the range of possibilities, the following two sections compare the responses of two hypothetical economies, one with perfect flexibility of prices and wages and the other with absolute rigidity in the nonfarm sector. These cases serve to illuminate the more complicated and relevant analysis of a realistic economy in which nonfarm prices and wages are neither perfectly flexible nor absolutely fixed.

\section{PERFECT PRICE FLEXIBILITY}

The economy encounters no problems in adjusting to an external shocksay, a crop failure-if both farm and nonfarm prices and wages are perfectly flexible. In this case the market for nonfarm goods and labor always clears, and no involuntary unemployment can arise. A brief examination of this case serves as a point of comparison with the diametrically opposite case of fixed prices.

The treatment of all cases incorporates several common assumptions. The economy is closed, with all output of both sectors produced and consumed in the domestic economy. Farm output is exogenous, produced by a factor that is not mobile between the two sectors and consumed entirely in the nonfarm sector. The exogenous supply of farm output, $Q_{F}$, is equated to the demand:

$$
Q_{F}=A Q_{N}{ }^{a} 0\left(\frac{P_{F}}{P_{N}}\right)^{-a} 1
$$

where $A$ is a constant, $a_{0}$ is the nonfarm income elasticity of demand for farm products, $a_{1}$ is the absolute value of the price elasticity (which throughout the paper is assumed to be less than unity), and $P_{F}$ and $P_{N}$ are, respectively, price indexes for farm and nonfarm output. A rearrangement of 
(1) relates the market-clearing relative price, $P_{F} / P_{N}$, to the exogenous supply of farm output and the level of nonfarm output, $Q_{N}$ :

$$
\frac{P_{F}}{P_{N}}=\left[\frac{A Q_{N}{ }^{a} 0}{Q_{F}}\right]^{1 / a}
$$

For any given supply of farm products, an increase in nonfarm output raises the demand for farm products, and hence the relative price, by an amount that depends positively on the income elasticity, $a_{0}$, and negatively on the price elasticity, $a_{1}$. The relative price depends, in part, on the level of nonfarm output, except in the special case of a zero income elasticity.

Nonfarm output is assumed to be produced with labor and some other fixed factor, like capital. Knowledge and technology is assumed fixed, so that labor input determines nonfarm output. Given the population, if the supply of labor does not respond to changes in the real wage, both labor input and nonfarm output are fixed. In this case, a crop failure changes the relative price of farm products but not the level of nonfarm output. Since the wage rate that nonfarm firms can afford to pay to a given number of workers is limited by nonfarm prices, any increase in the relative price of farm products reduces the real wage of workers, when the latter is defined in terms of a consumer price index including both farm and nonfarm products.

If, however, a lower real wage causes workers to reduce their labor input, either by withdrawing from the labor force or by working fewer hours per week, a crop failure must reduce nonfarm output. ${ }^{4}$ This response in the nonfarm labor market thus provides a second relationship between nonfarm output and the relative price of farm products, in addition to equation (2) above, allowing the simultaneous determination of both variables. ${ }^{5}$ Hence, output and relative prices in each sector are beyond the control of

4. A third case, not discussed here, is a negatively sloped labor supply curve. Most cross-section evidence for the United States appears to support a vertical curve for adult male workers, a positively sloped response of women and teenagers to an increase in their own real wage, and a negative response of wives to an increase in their husbands' real wage. See the evidence cited in Robert J. Gordon, "The Welfare Cost of Higher Unemployment," BPEA (1:1973), table 2, p. 159.

5. The exact form of the second relationship is

$$
Q_{N}=D\left(\frac{k P_{F}}{P_{N}}+1-k\right)^{-e(b-1) /(b+e)}
$$

where $D$ is a constant, $k$ is the share of farm products in consumer expenditures, and $b$ and $e$ are, respectively, the elasticities of the nonfarm labor demand and supply curves. 
policymakers. If the choices of individuals between leisure and labor are socially accepted, any reduction in employment caused by the voluntary withdrawal of labor input in response to a lower real wage is of no concern for stabilization policy, since that reduction is purely voluntary.

What, if anything, can stabilization policy accomplish when nonfarm prices are perfectly flexible? Aggregate-demand policy controls the level of nominal income (that is, gross national product in current dollars), which is sufficient to set the nominal nonfarm price level since the values of all real variables have been determined. If policymakers follow a rule that calls for constant nominal income, then a crop failure must cause nominal nonfarm prices to fall, but the overall average price level must rise. ${ }^{6}$ If, on the other hand, policymakers achieve constant overall prices by reducing nominal income, they would prevent a redistribution of income from creditors and pensioners to debtors. Even if the expected rate of inflation and the level of the interest rate are unaffected, the higher the price level, the smaller the fraction of income a debtor will require to service his debts.

Whether or not the labor supply shrinks in the flexible-price case, the welfare of nonfarm workers is reduced. ${ }^{7}$ Not only does a crop failure reduce total real output, but also, as long as the demand for farm products is price inelastic, it transfers income from workers to farmers, who enjoy a windfall. While the problem is not one of stabilization, society might wish to reduce or eliminate the transfer by a redistributive tax policy that, for example, levies a windfall-profits tax on farmers to finance a subsidy on nonfarm products purchased by nonfarm workers. However, the case for redistributive tax-subsidy schemes is not obvious, nor is there an obvious line between temporary events justifying redistribution and those that do not.

\section{COMPLETE WAGE AND PRICE RIGIDITY}

In the case of perfect price flexibility, nonfarm output is either fixed or determined by workers' decisions about labor supply, leaving the nonfarm price level to be determined by stabilization policy. If, on the other hand,

6. The nonfarm price level falls if the price elasticity of demand for farm products is (approximately) less than unity; the overall price level must rise, because real output has fallen and nominal income is assumed constant.

7. Although workers who reduce labor input obtain leisure worth the real wage at the margin, they lose part of their producers' surplus earned on inframarginal units of work. In parallel fashion, farmers gain a producers' surplus from the increase in the relative price of their output. 
the nonfarm wage rate is rigid and nonfarm prices are "marked up" over the wage rate by a constant fraction, then nonfarm prices are fixed and nonfarm real output is determined by stabilization policy.

Nominal income, $Y$, is the sum of total nominal spending in each sector:

$$
Y=P_{F} Q_{F}+P_{N} Q_{N}
$$

equation (2) can be substituted into (3) to obtain

$$
\left.Y / P_{N}=\left[A Q_{N}^{a} 0 Q_{F}^{-(1-a)}\right]^{(1 / a}{ }_{1}\right)+Q_{N} .
$$

When nominal income is held fixed by a policy rule, the wage rate and nonfarm prices are rigid, and the demand for farm products is income and price inelastic $\left(a_{0}<1\right.$ and $\left.a_{1}<1\right)$, then nonfarm output varies in the same direction as farm output, even if the supply of nonfarm labor is completely unresponsive to changes in the real wage. Since the value of farm output rises and nominal income is fixed, the value of nonfarm output must fall. With nonfarm prices rigid, nonfarm output must drop, causing involuntary unemployment. The crop failure thus carries with it a real "multiplier" effect. Just as stabilization policy can alter nominal nonfarm spending and the price level of the nonfarm sector in the flexible-price case, so it can alter that sector's nominal spending, real output, and employment in the rigid-wage case.

In this extreme case, the multiplier can be derived when the marketclearing condition for farm output, (2) above, is written in the form of percentage changes:

$$
p_{F}-p_{N}=\frac{-q_{F}+a_{0} q_{N}}{a_{1}}
$$

where lower-case $p$ s and $q$ s denote percentage changes between the initial situation and the new situation after the crops have failed:

$$
p_{F}=\left(P_{F_{1}}-P_{F_{0}}\right) / P_{F_{0}} \text {. }
$$

If policymakers hold nominal income constant, the change of nominal income - that is, a weighted average of spending in the two sectors as defined in (3) above-must be zero:

$$
y=0=k\left(p_{F}+q_{F}\right)+(1-k)\left(p_{N}+q_{N}\right)
$$

where $k$ is the share of farm spending in total spending. Substituting (5) 
into (6) yields, after some rearrangement, the percentage change in nonfarm output relative to the exogenous change in farm output:

$$
\frac{q_{N}}{q_{F}}=\frac{k\left(1-a_{1}\right)}{k a_{0}+(1-k) a_{1}} .
$$

To take a simple example, assume that the initial share of expenditure in the farm sector, $k$, is 10 percent, and that the income and price elasticities are, respectively, zero and 20 percent $\left(a_{0}=0\right.$ and $\left.a_{1}=0.2\right)$. In this case the elasticity of nonfarm output to a change in farm output is $4 / 9$. With initial levels of expenditure of $\$ 100$ billion and $\$ 900$ billion in the two sectors, a 10 percent loss in farm output ( $\$ 10$ billion) causes a 4.44 percent decline in nonfarm output ( $\$ 40$ billion). Thus the social cost, $C$, of the $\$ 10$ billion crop failure is

$$
\begin{aligned}
C & =-\left[k q_{F}+(1-k) q_{N}\right] Y=\frac{-k q_{F} Y}{a_{1}} \\
& =\frac{\$ 10 \text { billion }}{0.2}=\$ 50 \text { billion. }
\end{aligned}
$$

Since the nonfarm price level is rigid, policymakers can fully offset the multiplier effect of the crop failure on nonfarm output with no deleterious side effects. Nominal income must simply increase sufficiently to leave nonfarm output unchanged by the crop failure. This "fully accommodating" policy response can be calculated from (6) when $q_{N}$ (as well as $p_{N}$ ) is equal to zero:

$$
y=k\left(p_{F}+q_{F}\right)=-q_{F} \frac{k\left(1-a_{1}\right)}{a_{1}} .
$$

With the parameters of the previous example, nominal income should be raised by 4 percent $-\$ 40$ billion - to counteract the $\$ 40$ billion loss of nonfarm output that would have occurred had nominal income been allowed to remain fixed.

The consumer price index, an average of the fixed nonfarm price and the higher farm price, must rise, and policymakers cannot avoid accepting this higher overall price level, just as they cannot re-create the lost crops. ${ }^{8}$ But

8. A positive value for the income elasticity of demand for farm products reduces the multiplier, since lower nonfarm output moderates the increase in the relative price needed to clear the farm output market, and this in turn releases more of the fixed level of nominal income for the support of nonfarm output. When $a_{0}=0.2$, the elasticity of nonfarm output is reduced from 4.44 to 4.0 percent, the social cost from $\$ 50$ billion to $\$ 46$ billion, and the necessary nominal income offset from $\$ 40$ billion to $\$ 36$ billion. 
stabilization policy can eliminate the wasteful "multiplier" loss in nonfarm output and associated involuntary nonfarm unemployment by providing enough extra nominal income to make room for both the original level of nonfarm spending (fixed price and initial real output) and the higher level of spending on farm products. ${ }^{9}$

\section{Partial Price Adjustment}

\section{NO COST-OF-LIVING EFFECT ON WAGES}

At this point the policymaker is torn between the conflicting advice of the flexible-price model, which recommends a reduction in nominal income to stabilize the price level, and that of the rigid-price model, which recommends an increase in nominal income to avoid involuntary unemployment. The simplest intermediate model allows the rate of change of nonfarm prices $\left(p_{N}\right.$, where small letters now denote percentage changes per unit of time) to adjust by a fraction, $\lambda$, of the difference between the market-clearing value of the flexible price, $\hat{P}_{N}$, and the current price, $P_{N}$ :

$$
p_{N}=\lambda\left(\hat{P}_{N}-P_{N}\right) \text {. }
$$

When nominal income is held constant, $\hat{P}_{N}$ during the period of the crop failure lies below the initial nonfarm price level $\left(P_{N_{0}}\right)$ and the rate of change of nonfarm prices is negative until they are brought into line with $\hat{P}_{N}$. Since $P_{N_{0}}$ lies above the market-clearing value, $\hat{P}_{N}$, the initial consequence of the crop failure is a decline in nonfarm output and the creation of involuntary unemployment, as in the rigid-price analysis of the previous section. Through time, however, downward adjustment of the nonfarm price level makes more of nominal income available for nonfarm output, and the severity of the recession is gradually mitigated. Finally, $P_{N}$ ends its decline when it reaches its market-clearing level, $\hat{P}_{N}$, at which point involuntary unemployment is eliminated. The process is reversed when the crops return to normal; at the low nonfarm price level, $\hat{P}_{N}$, the constant level of nominal income allows nonfarm output to rise above its initial value, and an output and employment "boom" continues until $P_{N}$ has returned to $P_{N_{0}}$.

The temporary recession, as well as the subsequent temporary boom in

9. Nonfarm output might have fallen as in the flexible-price case if the supply of labor were voluntarily reduced in response to the lower real wage. 
output, can be eliminated, as described in the previous section, by a policy of accommodating nominal income. If nominal income is raised by the amount calculated in equation (9), the market-clearing value of $\hat{P}_{N}$ during the period of the crop failure is by definition equal to the initial price level, $P_{N_{0}}$, and no downward adjustment in nonfarm prices takes place. Now a policy of accommodating nominal income imposes on society the cost of a higher price level than one that aims at constant nominal income, and a more substantial (albeit temporary) redistribution from creditors and pensioners to debtors. The choice between the policies has no long-run consequences for the level of prices or output, or for the rate of inflation. ${ }^{10}$

\section{SOME COST-OF-LIVING EFFECTS ON WAGES}

The previous section assumes that higher farm prices have no direct effect on nonfarm wages and prices, and thus ignores the possibility that a policy of accommodating nominal income may permanently increase the rate of inflation. As a point of departure for developing a more realistic mechanism for adjusting nonfarm prices, which allows for the possibility of an equilibrium nonzero inflation rate, (10) may be reformulated as

$$
p_{N}=p_{N}^{*}+j Z,
$$

where $p_{N}^{*}$ is the rate of change of the expected nonfarm price level, $Z$ is the excess demand for labor, and $j$ is an adjustment coefficient. Assume that the expected level of nonfarm prices remains constant $\left(p_{N}^{*}=0\right)$ after a crop failure; then, so long as the price level is above its market-clearing value$P_{N}>\hat{P}_{N}$ in (10)-the resulting involuntary nonfarm unemployment means that $Z<0$ in (11).

Equation (11) is simply an "expectational Phillips curve," the properties of which have received extensive analysis and empirical testing in recent years. A slightly more complicated but substantially more realistic version can be developed if (ignoring productivity change) it is assumed that the rate of growth of the wage rate, $w$, is equal to that of the expected price level plus a fraction, $j$, of the excess demand for labor, $Z$ :

$$
w=p^{*}+j Z \text { : }
$$

The expected price level relevant for wage decisions is a weighted average of

10. Such consequences might ensue to the extent that the recession-inducing policy cuts real investment and thus endows future generations with a lower capital stock. 
the expected nonfarm price, $P_{N}^{*}$, which defines the value of labor's marginal product, and the expected consumer price index, $P_{C}^{*}$, adjusted for the payroll-tax factor, $T^{*}$, used by workers to calculate their real after-tax wage rate. Thus (12) becomes ${ }^{11}$

$$
w=g\left(p_{C}^{*}+t^{*}\right)+(1-g) p_{N}^{*}+j Z .
$$

When the coefficient $g$ is greater than zero, the wage rate depends not only on the nonfarm product price, but also on farm prices and the payroll tax rate. In the extreme case, when $g$ has a value of unity, all of the increase in consumer prices relative to nonfarm product prices resulting from a crop failure is passed through to the wage rate, and real wages do not fall. When the wage equation is interpreted as the adjustment path in a neoclassical model of the labor market, the parameter $g$ is the ratio of the elasticity of the labor supply curve to the sum of that elasticity and the elasticity of the demand curve, and is zero when the supply of labor does not respond to changes in the real wage. ${ }^{12}$ But in alternative labor market settings the value of $g$ might be nonzero even if labor were supplied inelastically. In unionized industries, for instance, the strike weapon might be used to pass through some or all of an increase in farm prices in higher wages. Quite apart from unions, competitive firms might offer risk-averse employees a wage contract indexed to the consumer price index, trading this real-wage insurance for a reduction in the average real wage. ${ }^{13}$ The following analysis

11. Equation (13) has been estimated in Robert J. Gordon, "Inflation in Recession and Recovery," BPEA (1:1971), table 1, equation (11). The equation has also been used in empirical work for the United Kingdom by Michael Parkin and his collaborators and has been derived explicitly in Michael Parkin, Michael T. Sumner, and R. Ward, "The Effects of Excess Demand, Generalized Expectations, and Wage-Price Controls on Wage Inflation in the U.K.," in Karl Brunner (ed.), a conference volume on controls (Amsterdam: North-Holland, 1975), forthcoming.

12. A more complex version with several varieties of taxes, cyclical variations in productivity growth, and other complications, is analyzed in Robert J. Gordon, "Interrelations between Domestic and International Theories of Inflation," in R. Z. Aliber (ed.), The Political Economy of Monetary Reform, forthcoming.

13. The idea of "wage insurance" as an explanation of rigid wages was developed simultaneously and independently by C. Azariadis, "Implicit Contracts and Underemployment," Journal of Political Economy, vol. 83 (1975), forthcoming; Martin N. Baily, "Wages and Employment under Uncertain Demand," Review of Economic Studies, vol. 41 (January 1974), pp. 37-50; and Donald F. Gordon, "A Neo-Classical Theory of Keynesian Unemployment," in Karl Brunner and Allan Meltzer (eds.), The Phillips Curve and Public Policy, Carnegie-Rochester Conference Series, vol. 1 (Amsterdam: North-Holland, 1975). 
will discuss the consequences of different values of $g$ as though they result from an expectational mechanism in wage bargaining, but the interpretation could readily be adapted to cover other cases.

An equation for the price of output in the nonfarm sector is now required. In line with considerable evidence, the nonfarm price level is set as a "markup fraction" multiplied by "standard" unit labor cost-that is, the wage rate divided by productivity at some "standard" level of capacity utilization - with the size of the markup fraction dependent on the demand for commodities. ${ }^{14}$ Assuming a constant level of standard productivity (equal to 1.0), the price equation becomes

$$
P_{N}=W X^{c},
$$

where $X$ is an index of excess commodity demand and $c$ is the percentage response of the inflation rate to the rate of growth of output.

When the wage and price equations are combined with the definition of consumer prices,

$$
P_{C}=P_{F}^{k} P_{N}^{(1-k)},
$$

a relationship between changes in nonfarm and farm prices is obtained:

$$
p_{N}=(1-g k) p_{N}^{*}+g\left(k p_{F}^{*}+t^{*}\right)+j Z+c x .
$$

As in equation (11), the basic force that allows involuntary unemployment to persist is the partial downward adjustment of prices in the face of excess labor (and commodity) supply. What difference is made by a value of $g$ greater than zero? The analysis is identical to that of (11), of course, if the expected farm price is unaffected by a temporary increase in the actual level. On the other hand, a crop failure may lead individuals to revise upward the level of farm prices that they expect during their wage contracts (in 1972-74, U.S. domestic food consumers had "three lean years"). In this case a "wage push" is exerted by farm prices, which raises the nonfarm price level above the adjustment path described by (10) and (11), in turn "using up" more of the fixed level of nominal income, raising the multiplier, and aggravating the recession.

If $g$ is positive and if expected farm prices respond to the higher actual level, the results depend on how expectations adjust to price changes in the nonfarm sector. One possibility is that expectations adapt to past changes in

14. See the evidence presented in Gordon, "Inflation in Recession and Recovery," p. 129 . 
nonfarm prices. The expected level of nonfarm prices for the next period would then be set equal to the current level extrapolated by an expected rate of nonfarm inflation estimated from its past rate. Just after a crop failure, such adaptive nonfarm expectations would worsen inflation, since nonfarm price expectations would be raised in response to the higher current price level caused by the feedthrough of farm prices to wages..$^{15} \mathrm{And}$, if nominal income is held constant, the higher level of nonfarm prices worsens the initial stages of the recession. But soon the adjustment of nonfarm price expectations would begin to operate in the opposite direction, reducing inflation and the magnitude of the recession, since it would amplify the downward adjustment of nonfarm wages and prices in response to excess labor supply.

In short, adaptive nonfarm price expectations amplify the fluctuations in nonfarm output and prices in response to a crop failure as long as nominal income is held constant. If, on the other hand, policymakers pursue a fully accommodating policy for nominal income, which prevents the emergence of excess labor supply, adaptive expectations raise expected nonfarm pricesthe "base" around which the adjustment of prices takes place-and endow the economy with a permanently higher price level. So long as the crop failure is temporary, the rate of inflation is not permanently affected, since the decline in farm prices at the end of the failure feeds through to expectations and ends the upward adjustment of expected nonfarm prices. But an accommodating policy for nominal income would permanently raise the rate of inflation in the case of a permanent supply reduction, brought about, for example, by an eternal oil cartel.

\section{The Potential for Tax Policy}

In any realistic case, a policy accommodating nominal income (such as an increase in the money supply sufficient to eliminate the nonfarm multiplier effect of a crop failure) has the disadvantage of raising the price level

15. Corresponding to (7) above is a multiplier formula that takes into account the feedthrough of farm prices to wages (but not the effect on prices of excess labor or commodity supply):

$$
\frac{q_{N}}{q_{F}}=\left\{\frac{k\left[\left(1-a_{1}\right)(1-g k)+g\right]}{a_{0} g k+\left[k a_{0}+(1-k) a_{1}\right](1-g k)}\right\} .
$$

Compared to the case $a_{1}=0.2, a_{0}=0.2$, and $g=0$, which yields an elasticity of 0.4 , the 0.2 value for $g$ (assumed in the simulation below) increases the elasticity to 0.492 . 
relative to an alternative policy aimed at constant nominal income. Changes in tax rates and subsidies, on the other hand, not only operate on income but also can directly alter the price level. A reduction in the payroll tax rate, for instance, narrows the "wedge" between market prices and aftertax factor cost, and hence allows firms to charge a lower price while paying workers the same after-tax wage rate. Along with a reduction in tax rates, policymakers must take steps (cutting government expenditures or the money stock, for example) to maintain, as I shall assume, an unchanged path of nominal income. ${ }^{16}$

A reduction in taxes will lower consumer prices most if applied to those taxes whose burden is borne by consumers rather than factors of production. At one extreme, changes in state sales taxes are probably shifted forward to consumer prices by nearly 100 percent, while at the other extreme, changes in the corporation income tax affect mainly capital income and do not appear to be substantially shifted forward. ${ }^{17}$ The personal income tax is an intermediate case and appears to be shifted forward to consumers by roughly 20 percent. ${ }^{18}$ In the absence of a universal federal sales tax, the policy option that would yield the greatest reduction in prices for a given loss of revenue would be a federal government bribe to induce reductions in state and local sales taxes. If this mechanism were rejected as administratively clumsy or politically infeasible, the federal government could subsidize nonfarm output to offset the impact of the higher farm prices on the consumer price index..$^{19} \mathrm{~A}$ constant nominal income would thereby be sufficient for both the higher farm-price level needed to clear that market and the original level of nonfarm output, since the after-subsidy nonfarm price would be pushed down to the market-clearing level, $\hat{P}_{N}$. The size of the required subsidy relative to GNP is given by equation (9)-for instance, $\$ 40$ billion in the simple example spelled out above.

Possibly, such a subsidy could be financed by a windfall-profits tax on

16. In principle, if no offsetting action is taken, the price level may be either raised or lowered. See Alan S. Blinder, "Can Income Tax Increases Be Inflationary? An Expository Note,” National Tax Journal, vol. 26 (June 1973), pp. 295-301.

17. Robert J. Gordon, "The Incidence of the Corporation Income Tax in U.S. Manufacturing, 1925-62," American Economic Review, vol. 57 (September 1967), pp. 731-58.

18. See Gordon, "Inflation in Recession and Recovery," table 1, where the tax coefficient refers to the personal income tax plus the social security tax paid by employees.

19. A subsidy for farm products would raise demand above the reduced supply and hence would be infeasible without a commodity inventory or buffer stock. A subsidy for nonfarm products would not require higher nonfarm output than initially, but would simply offset the multiplier effect and allow the original full employment level of nonfarm output to be maintained. 
farmers if society felt this temporary event justified income redistribution. Another alternative would be bond finance, which would redistribute income from future generations to present ones. Still another solution would be the establishment of a "price stabilization fund" that would pay nonfarm subsidies in years of low farm production, financed by a nonfarm sales tax in years of bumper crops and low farm prices. ${ }^{20}$ Symmetric supply fluctuations would allow this remedy, but asymmetric events like those engendered by the OPEC oil cartel would not.

\section{The Inflationary Consequences of an Accommodating Policy}

A nonfarm subsidy appears to be almost ideal in principle, eliminating involuntary nonfarm unemployment and averting most (but not all) of the increase in consumer prices. ${ }^{21}$ But its rapid implementation may pose administrative or political issues, and its financing raises difficult problems. An alternative is an accommodating policy for nominal income, which could eliminate involuntary nonfarm unemployment at the cost of a higher price level.

A rough numerical estimate of these inflationary consequences is presented in figure 1. A simple model has been simulated to illustrate the consequences of a hypothetical 10 percent decline in farm output lasting twelve quarters. The model consists of the farm market-clearing equation (2) combined with the nonfarm price adjustment equation (16). The simulated response of the rate of wage increase to excess labor supply is relatively slight, as U.S. evidence suggests, but excess commodity demand is assumed to have a substantial impact on nonfarm prices relative to wages. Other parameters are identical to those used in the multiplier examples in the previous section (details are spelled out in the appendix).

The "basic" simulation, $A$, illustrated by the solid line in figure 1 , shows that a crop failure accompanied by a policy of constant nominal income creates a recession, the severity of which gradually eases as nonfarm prices adjust downward in response to excess supply. The "optimistic accommodation" simulation, $B$, assumes that policymakers raise nominal income to maintain the original level of nonfarm output and that the expected level of

20. Inventories of farm products are ruled out by the assumption that the supply shock is sufficiently severe to exhaust them.

21. See note 6 above. 

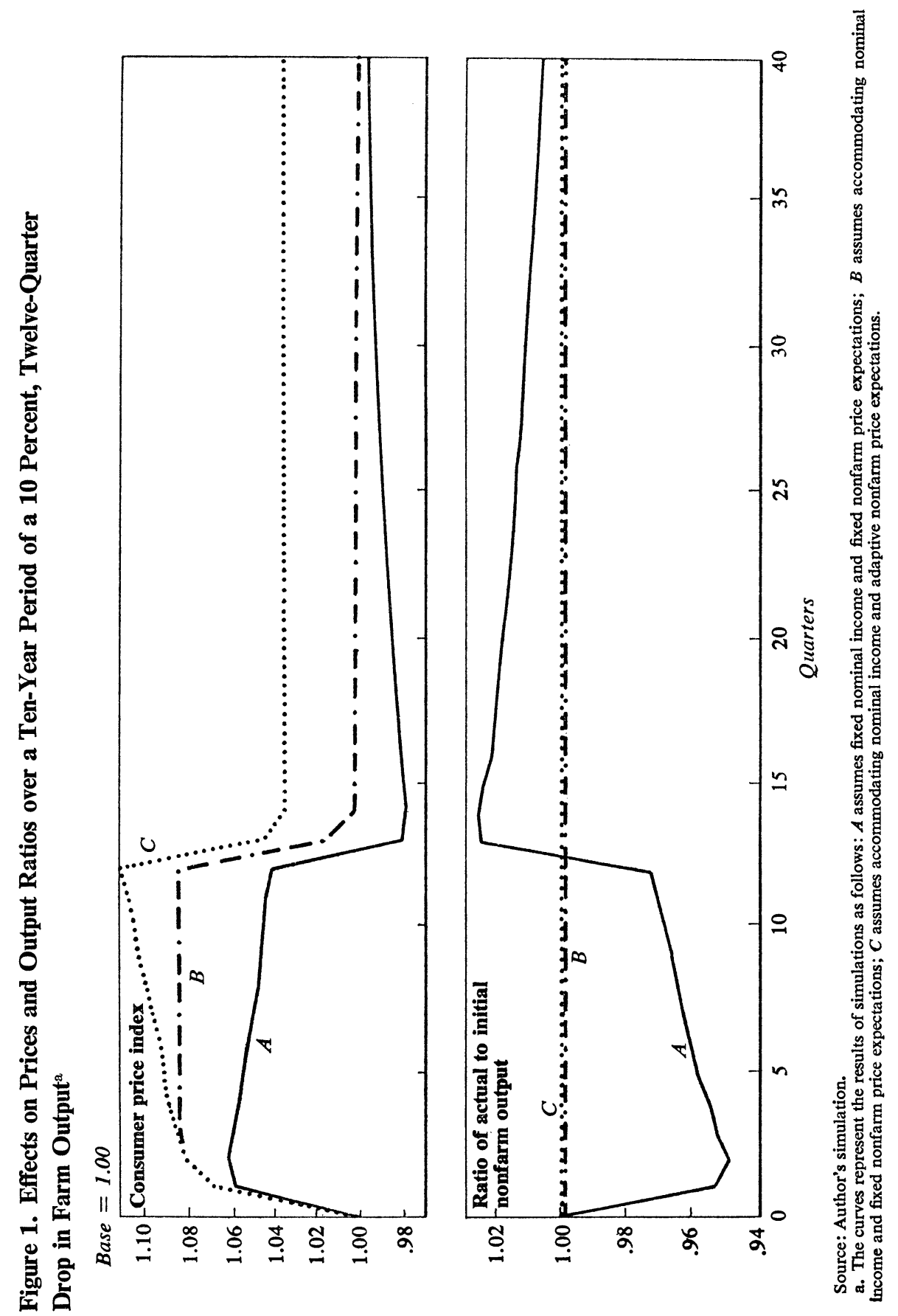
farm prices is adjusted upward to the higher actual farm price, but that individuals maintain their expectations about nonfarm prices. The "pessimistic accommodation" simulation, $\mathrm{C}$, assumes that the expected level of nonfarm prices is adjusted adaptively to all changes in actual nonfarm prices, whether associated with temporary or permanent events. Simulation $B$ illustrates that an accommodating policy buys full employment at the cost of a temporary increase in the price level and in the rate of inflation; but it permits more deflation after the crops return to normal, leaving the consumer price index the same ten years after the initial shock. In simulation $C$, the inflation rate increases by more than it does in the optimistic case but nevertheless temporarily; the consumer price index is permanently increased by almost 4 percent as the result of the gradual upward adjustment of the expected rate of nonfarm inflation during the period of the crop failure.

\section{The Consequences of Wage Indexing}

The computer simulation program can also be used to evaluate the consequences of an external shock for an economy in which wages are indexed. Wage indexing can be represented by a new wage equation to replace (13):

$$
w=p_{C}+j Z \text {. }
$$

The rate of change of the real wage rate $\left(w-p_{C}\right)$ now depends only on excess labor demand. By increasing the stability of the real wage, wage indexing makes wages and prices more responsive and real output less responsive to "nominal" shocks-that is, variations in monetary growth. At the same time, however, the built-in rigidity of the real wage impedes the economy's adjustment to "real" shocks, which require a change in the real wage. ${ }^{22}$ In (17) the reduction in the real wage needed to clear the market for farm output calls for a deeper recession with indexing than without.

Figure 2 contrasts the path of the consumer price index and nonfarm output in the basic nonindexed simulation $A$ from figure 1 with two indexing simulations. The behavior of the wage rate under indexing is represented by (17), adjusted to make the current rate of wage change equal to the rate

22. The sentence summarizes the major conclusion of Jo Anna Gray, "Wage Indexation: A Macroeconomic Approach," working paper (University of Chicago, April 1975; processed). 
<smiles>C#CC1C#CC#C1</smiles> 
of change of the CPI in the previous period, adjusted for that period's excess labor demand. Curve $D$ in figure 2 traces the effects of wage indexing when policymakers hold nominal income constant. The increase in farm prices during the crop failure feeds through much more completely to wages and nonfarm prices when wages are indexed, using up more of the fixed nominal income and requiring a much more substantial decline in real output (reaching a maximum of nearly 15 percent) than in the basic simulation. Eventually, the deep recession brings down the price level, freeing more of nominal income to support real output. When the crop failure ends, a very large excess demand for labor develops. In short, wage indexing makes both prices and unemployment substantially less stable when nominal income is held constant in the presence of an external supply shock.

As before, policymakers can raise nominal income to accommodate both higher farm prices and the original level of nonfarm output. But this policy has very serious inflationary consequences under wage indexing, since it prevents the emergence of the excess labor supply required in the lagged version of (17) to lower the real wage. As illustrated by curve $E$ in figure 2, the result is a geometric increase in the consumer price index (a steady 6.0 percent quarterly rate of inflation) until farm output returns to its initial level in the thirteenth quarter, by which time the consumer price index has doubled. Only a bumper crop or a policy-induced recession can reverse the process and bring the consumer price index back down.

\section{Summary and Conclusions}

This paper analyzes the response of a simple two-sector economy to a decline in output in an external sector where the price is assumed to clear markets. Its major conclusions are, first, that no problems arise if wages and prices in the internal sector instantly fall to clear the market. Any reduction in employment is purely voluntary. The optimal policy is a reduction in nominal income to hold the aggregate price index constant and avoid a temporary increase in its level.

Second, when nonfarm wage and price levels are absolutely rigid, and when nominal income is held fixed, the supply reduction in the external sector has a multiplier effect, causing a recession and involuntary unemployment in the internal sector. The "social cost" of the supply reduction then 
exceeds the value of lost external output by the value of the nonfarm output that is squeezed out. The optimal policy is an increase in nominal income designed to accommodate both the higher external price level and the original level of internal output; a temporary increase in the aggregate price level cannot be avoided since the internal price level is fixed.

Third, when wages and prices are partially responsive to excess labor and commodity demand but wages do not respond directly to higher external prices, the initial effect of the external supply reduction is the same as in the rigid-price case. If nominal income is held constant, a recession will continue until the nonfarm price has fallen to its market-clearing level. As in the rigid-price case, the recession can be avoided by an accommodating policy for nominal income, which temporarily (but not permanently) raises the price level compared with the case when nominal income is held constant.

Fourth, when wages and prices are partially responsive to excess labor and commodity demand, and in addition external prices feed through directly to wages, the inflation and recession caused by the external supply shock are both aggravated. A policy aimed at an accommodating nominal income raises the price level temporarily but not permanently higher than would one of nonaccommodation if expectations of the nonfarm price level do not extrapolate the inflation that occurs during the period of the supply reduction. On the other hand, adaptive nonfarm expectations would cause the price level (but not the rate of inflation) to remain permanently higher when an accommodating policy is pursued. Moreover, in the event of a permanent reduction in supply (such as one enforced by an unbreakable oil cartel), a policy of accommodating nominal income would raise permanently the rate of inflation of the consumer price index.

For the case of the temporary crop failure, a superior policy in principle would be a subsidy to nonfarm products that would avert both the recession entailed by nonaccommodation, and the higher price level required by accommodation. The major obstacles to a subsidy are the administrative and political difficulties of its prompt implementation, and the costs of financing it.

Finally, the analysis of this paper raises serious questions about the merits of the full indexation of wage contracts, which would shorten the lag in the adjustment of wages to changes in external prices and would thus inhibit the decline in the real wage required by an external supply shock. If policymakers attempt to stabilize nominal income in a wage-indexed econ- 
omy, any external shock will destabilize both prices and output more than it would in an unindexed economy. Any attempt to accommodate the higher prices by raising nominal income under indexing will impose on the economy a substantially higher inflation rate for the duration of the external supply reduction. These disadvantages of wage indexation seem to me persuasive, but do not weaken my previously stated support for fully indexed government bonds, tax exemptions, and tax brackets.

\section{APPENDIX}

\section{Model Used for Simulations}

IN THIS DESCRIPTION of the model, superscripts refer to sectors, and subscripts to time periods. (The basic parameter assumptions and their justifications are listed at the end of this appendix.) Farm output, $Q_{t}^{F}$, depends on its base-period level, adjusted by a percentage crop failure, $v$ :

$$
Q_{t}^{F}=(1-v) Q_{0}^{F} \text {. }
$$

From (2) in the text,

$$
P_{t}^{F}=P_{t-1}^{N}\left[A\left(Q_{t}^{N}\right)^{a} 0 / Q_{t}^{F}\right]^{1 / a} 1 .
$$

From (13),

$$
w_{t}=p_{t}^{N^{*}}+j Z_{t-1}+g\left(k p_{t}^{F}+t\right),
$$

where the expected farm prices and the tax rate are set at their actual values, and the symbols are as defined in the text equations. With the rate of growth of output as a proxy for the rate of growth of excess commodity demand, from (14):

$$
p_{t}^{N}=w_{t}+c q_{t-1}^{N} .
$$

The consumer price index is

$$
P_{t}^{C}=k P_{t}^{F}+(1-k) P_{t}^{N} .
$$

(I have omitted equations that convert levels to rates of growth, and vice versa.) When expectations are adaptive, the expected level of nonfarm prices is extrapolated from the actual level of the previous period by an expected inflation rate that is a distributed lag of past inflation rates, with 
weights from my "Inflation in Recession and Recovery," table A-1, truncated to the first ten values and constrained to add to unity:

$$
P_{t+1}^{N^{*}}=P_{t}^{N}\left(1+\sum_{i=1}^{10} u_{i} p_{t-i}^{N}\right),
$$

where the $u_{i}$ are the weights. The expected farm price level, $P_{t}^{F^{*}}$, is always equal to its actual value, $P_{t}^{F}$.

In the simulations that hold nominal income, $Y_{t}$, constant, the level of nonfarm output is a residual, and labor demand fluctuates by a fraction, $n$, of the change in output, while labor supply is assumed constant:

$$
Q_{t}^{N}=\left(Y_{0}-P_{t}^{F} Q_{t}^{F}\right) / P_{t}^{N}
$$

therefore, the excess demand for labor, $Z_{t}$, is

$$
Z_{t}=Z_{t-1}\left(1+n q_{t}^{N}\right) \text {. }
$$

In the simulations that vary nominal income to hold real nonfarm output constant, (A-7) and (A-8) are replaced by

$$
Y_{t}=P_{t}^{F} Q_{t}^{F}+P_{t}^{N} Q_{0}^{N}
$$

and

$$
Z_{t}=0 \text {. }
$$

In the simulations of wage indexing, (A-3) is replaced by

$$
w_{t}=p_{t-1}^{C}+j Z_{t-1} \text {. }
$$

The basic parameter assumptions and their justifications are as follows: $a_{1}$, the price elasticity of demand for farm products, is 0.2 , a value suggested to the author by Dale E. Hathaway. Hathaway also suggested 0.2 as a value for the income elasticity, $a_{0}$.

$v$, the percentage reduction in farm output, is 0.10 , an arbitrary choice. $j$, the percentage change in wage growth for a change of 1 percentage point in the excess demand for labor, is set equal to 0.13 , to correspond to the more pessimistic assumption in Tobin's recent BPEA paper..$^{23}$ (Note, however, that Tobin allows for no reaction in the price equation.)

$g$, the response of wage change to changes in farm prices, is 0.2 , roughly consistent with my evidence in "Inflation in Recession and Recovery," table 1.

23. James Tobin, "Monetary Policy in 1974 and Beyond," BPEA (1:1974), pp. 229-30. 
$c$, the percentage response of the inflation rate to the rate of growth of output, holding wage growth constant, is 0.15 . This implies that a 10 percent reduction of output relative to trend reduces the price-wage ratio by 1.5 percent. This is somewhat larger than the 1.0 percent estimate implied by the coefficient on the ratio of unfilled orders to capacity in "Inflation in Recession and Recovery," because of my finding that the transactions prices of producers' durable goods are flexible relative to the list prices used in that earlier paper. See my Measurement of Durable Goods Prices (National Bureau of Economic Research, 1975), forthcoming, chapter 5.

$k$, the share of the farm sector in initial spending, is 0.10 , an arbitrary choice.

$n$, the share of a change in output taking the form of a change in labor input, is set at 0.5 , allowing half of the output fluctuation to be reflected in productivity.

\section{Discussion}

William Poole questioned the relevance of Gordon's shock model to the actual situation of 1973-74. Poole pointed out that, historically, going back to the 19th century, serious inflations normally have been led by primary products. These commodities are traded in highly competitive markets and their supply elasticities are relatively low in the short run. Moreover, inventory speculation plays a major role in the determination of their prices. For these reasons, particularly large increases in the prices of primary products are a classic phenomenon of inflation. In Poole's judgment, the historical record at least raises questions that Gordon had not answered before assuming that agricultural shortages and the like played an unusual role in the 1973-74 experience. In response, Gordon emphasized that the shortfall in crops and the actions of the oil cartel were observable phenomena of recent years that properly could be regarded as shocks. The fact that these shocks impinged on a world with high levels of aggregate demand may dilute, but does not eliminate, the relevance of the shock model.

Another major reservation about the Gordon model was expressed by Martin Feldstein. He noted that wage rigidities were the basic reason that 
shocks produce recession in Gordon's model, and argued that these rigidities reflect the expectations of labor and management with respect to government policy. Basically, wages are rigid because private decisionmakers bet that the government will not let unemployment get so high as to pull down wages. Gordon's proposed policy of accommodating shocks by allowing nominal income to grow faster would strengthen these expectations, intensifying the downward rigidities and making it even harder to deal with new shocks.

Several discussants raised questions about how uncertainty of forecasting the exogenous sectors affected Gordon's findings. John Kareken called attention to the analytical problem of incorporating disturbances from stochastic variables like agricultural supplies into a comparative-statics model which essentially has no room for uncertainty. William Brainard agreed that stochastic models were needed to evaluate policy strategies to anticipate shocks. But he viewed Gordon's paper as a constructive attempt to assess the ability of policy to respond to shocks after they are known. He pointed out that, once a crop is harvested, some policy actions can influence the price level during the next year, even though a fully optimal response would depend upon the expected crop. Michael Wachter suggested that the recent record of agriculture could be viewed as a string of three shortage shocks in a row. It is tempting to accommodate each one of them individually as specific and transitory shortages to ease their impact; but a succession of such decisions accommodates inflation.

Some contrasting opinions were expressed about the nature of wage behavior insofar as it influences the value of the $g$ coefficient in Gordon's model. Robert Hall inferred from recent U.S. wage behavior that food and fuel prices had not fed through into wages. The real price of land and raw materials has risen in relation to real wages, just as supply and demand shifts dictated. James Tobin agreed with Hall that one did not observe, and should not have expected, a major escalation of money-wage increases as a result of rises in the prices received by entrepreneurs (like farmers and oil producers) who were not hiring labor. In fact, the employers of American labor did not have the wherewithal to pay major increases in wages. But he stated that neither the empirical nor analytical evidence demonstrated that the coefficient was zero rather than some small fraction-like the 0.2 value that Gordon used illustratively in his paper.

Franco Modigliani cautioned that the behavior of real wages gave no evidence of the magnitude of the pass-through into wages of cost-of-living 
items not produced by labor. Even if that pass-through was sizable, as long as all prices adjusted rapidly and fully to increases in wages, real wages would continue to be squeezed by the price rises in the exogenous sectors. He pointed to his own empirical results, which showed some effect of the price of wholesale foodstuffs on nonfood consumer prices, as evidence that some influence (although not a terribly strong one) prevails in reality. Feldstein thought that the recent moderation of wage increases might indicate that labor and management had made the same mistake as economists in underpredicting inflation. If they expected the food and fuel inflation to be temporary, their failure to pass those price increases into wages would be understandable.

Gordon's negative verdict on wage indexation interested a number of participants. In Brainard's view, wage indexation had undesirable effects in Gordon's model partially because wages are linked to a cost-of-living index that includes imports, food, and the like. If the price index comprised only items made by domestic workers, the results could be quite different and more favorable. Granting that such a form of indexation would offer less insurance on real wages to workers, Brainard thought that labor could recognize that real wages cannot be maintained in the face of major price increases in the exogenous sectors. Modigliani strongly supported Brainard's suggestion, contending that, for many purposes of indexation, the price index used for escalation should be restricted to value added in the private nonfarm sector. Hall felt that this was likely to approximate an indexing of wages by other wages, given the preponderance of wage costs in private nonfarm value added.

Marina Whitman noted that Gordon attributed a dual function to fiscal policy-influencing the cost as well as the demand side of the economy. This dual influence raised the possibility that an excise tax cut, for example, could bring down unemployment and yet have enough cost-reducing influence to curb inflation. She wondered whether it could ever be clear in the real world that the cost-reducing element of any tax cut would outweigh its demand-raising effects. Joseph Pechman elaborated on this point, stressing that the weapons in the arsenal of fiscal policy that can most readily exert cost-reducing effects are novel and thus far have been politically unsalable. 